\title{
PENGARUH VARIASI PENAMBAHAN ABU AMPAS TEBU TERHADAP FLOWABILITY DAN KUAT TEKAN SELF COMPACTING CONCRETE
}

\author{
Dhany Setyawan ${ }^{1}$, Fadillawaty Saleh ${ }^{1}$, Hakas Payuda ${ }^{1}$
}

\begin{abstract}
ABSTRAK
Self compacting concrete memanfaatkan berat sendirinya untuk dapat mengalir mengisi ruangan tanpa ada proses pemadatan sama sekali. Penggunaan abu ampas tebu sebagai pengganti sebagian semen dalam beton yang cukup tinggi mampu memperkecil ruang antar agregat sehingga beton yang dihasilkan lebih padat dan dapat meningkatkan sifat workability dan kemampuan alir beton. Pada umumnya Self compacting concrete memerlukan penggunaan superplasticizer untuk meningkatkan workabilitas dan daya alir beton . Tujuan dalam penelitian ini untuk mengetahui penggaruh penambahan abu ampas tebu sebagai pengganti sebagian dari semen pada sifat Self compacting concrete. Pembuatan benda uji menggunakan silinder berukuran diameter $15 \mathrm{~cm}$ dan tinggi $30 \mathrm{~cm}$ dengan 3 variasi abu ampas tebu sebesar $5 \%$, 10\%, dan $15 \%$ dan penambahan viscocrete dengan dosis yang berbeda yaitu 1,2\%,1,4\%, dan 1,6\% dari berat semen dan diuji pada umur 28 hari. Penambahan abu ampas tebu terhadap pengujian beton pada kondisi segar (fresh properties) dari variasi $3 \% ; 5 \%$ dan $15 \%$ telah memenuhi standar yang telah ditetapkan oleh EFNARC. Pada variasi penambahan abu ampas tebu 5\% ke $10 \%$ mengalami penurunan kuat tekan rata-rata sebesar $6,96 \%$ sedangkan pada variasi $10 \%$ ke $15 \%$ mengalami penurunan kuat tekan rata-rata sebesar $25,1 \%$.
\end{abstract}

Kata kunci : Compacting Concrete, Abu Ampas Tebu, Flowability.

\section{PENDAhuluan}

Salah satu pemecahan masalah untuk memperoleh struktur beton yang memiliki kepadatan serta ketahanan yang lebih baik adalah dengan menggunakan Self Compacting Concrete (SCC). Self Compacting Concrete (SCC) merupakan beton yang memiliki sifat kecairan (fluidity) yang tinggi sehingga mampu mengalir dan mengisi ruang-ruang di dalam cetakan tanpa proses pemadatan. Kemampuan mengalir dengan tingkat ketahanan terhadap segregasi yang tinggi pada SCC disebabkan oleh pembatasan kandungan dan ukuran agregat yang lebih kecil dari pada beton konvensional, rasio air-semen (w/c-ratio) yang rendah, serta penggunaan superplasticizer yang memadai. Berbeda dengan beton normal pada umumnya, komposisi semen yang dibutuhkan pada mix design Self Compacting Concrete (SCC) lebih banyak jika dibandingkan komposisi semen pada beton normal, selain itu Self Compacting Concrete (SCC) sebagai alternatif campuran beton yang memiliki volume pori-pori kecil, membutuhkan karakteristik yang sedikit berbeda dari beton konvensional. Diantaranya adalah agregat kasar yang digunakan memiliki ukuran yang relatif lebih kecil untuk mencegah terjadinya segregasi (Okamura dan Ouchi, 2003).

Self-Compacting Concrete (SCC) dapat diperoleh dengan cara variasi campuran beton yang ramah lingkungan dengan memanfaatkan bahan alam atau limbah industri, seperti kapur, abu terbang (fly ash), pasir besi, bubuk kaca, abu ampas tebu dan penambahan bahan tambah kimia (chemical admixture). Penggunaan limbah industri merupakan alternatif yang baik, oleh karena itu pada penelitian ini dicoba menambah abu ampas tebu dan dikaji terhadap kuat tekan beton. Abu ampas tebu (AAT) merupakan sisa hasil pembakaran dari ampas tebu. Ampas tebu sendiri merupakan limbah hasil buangan dari proses pembuatan gula. Dari uji porositas pada penelitian beton telah terbukti bahwa AAT dapat berfungsi sebagai pozzolan. AAT mempunyai kandungan $\mathrm{SiO}_{2}, \mathrm{Al}_{2} \mathrm{O}_{3}$,

${ }^{1}$ Staf Pengajar Jurusan Teknik Sipil Universitas Muhammadiyah Yogyakarta, hakas.prayuda@ft.umy.ac.id 
$\mathrm{Fe}_{2} \mathrm{O}_{3}, \mathrm{CaO}, \mathrm{K}_{2} \mathrm{O}, \mathrm{Na}_{2} \mathrm{O}, \mathrm{MgO}$, dan $\mathrm{P}_{2} \mathrm{O}_{5}$ yang berpotensi untuk digunakan sebagai bahan pengganti semen dan diharapkan menambah kuat tekan beton karena butirannya yang relativ kecil dan mampu mengisi lubang pori pada beton. Selain itu bahan tambah kimia (chemical admixture) seperti superplasticizer Sika Viscocrete-1003 dapat melarutkan gumpalan-gumpalan dengan melapisi pasta semen sehingga semen dapat tersebar dengan merata pada adukan beton dan mempunyai pengaruh dalam meningkatkan workability beton sampai pada tingkat yang cukup besar. Bahan ini digunakan dalam jumlah yang relatif sedikit karena sangat mudah mengakibatkan terjadinya bleeding. Superplasticizer dapat mereduksi air sampai $40 \%$ dari campuran awal (ASTM C494-82). Penggunaan superplasticizer pada SCC meningkatkan workabilitas dari beton segar dengan tidak berpengaruh banyak pada nilai kuat tekan beton tersebut. SCC yang masih segar memiliki nilai slump yang sangat tinggi, sehingga pengukuran dengan kerucut Abrams sudah tidak memungkinkan lagi. Pengukuran sifat SCC mengacu pada tingkat flowability serta passingability beton segar tersebut. Pengukuran sifat beton segar jenis self-compacting concrete dapat mengacu pada dua alat ukur yang berupa Slump-Flow Test dan L-Shape Box Test.

Tujuan penelitian ini untuk mengetahui pengaruh penambahan abu ampas tebu sebagai pengganti sebagian semen terhadap kuat tekan beton Self Compacting Concrete (SCC), mengetahui hasil pengujian beton segar SCC (filling ability, passing dan ability) dengan penambahan abu ampas tebu, mengetahui pengaruh superplasticizer viscocrete-1003 untuk pengujian Self Compacting Concrete (SCC) dan memperoleh hasil mengenai perilaku kuat tekan beton Self Compacting Concrete (SCC) dengan tambahan abu ampas tebu sebagai bahan tambahan pengganti semen dan superplasticizer Sika Viscocrete-10 pada umur 28 hari .

\section{METODOLOGI PENELITIAN}

2.1 Lokasi Penelitian

Penelitian dilakukan Laboratorium Teknologi Bahan Konstruksi, Jurusan Teknik Sipil, Fakultas Teknik, Universitas Muhammadiyah Yogyakarta.

2.2 Bahan Penelitian

Bahan-bahan yang digunakan dalam penelitian ini terdapat pada uraian berikut.

a. Agregat halus yang berupa pasir Merapi yang berasal dari Sungai Progo, Kabupaten Sleman, D.I. Yogyakarta.

b. Agregat kasar yang digunakan iyalah agregat yang di pecah/splite clereng asal Kabupaten Kulon Progo, D.I Yogyakarta.

c. Semen Portland yang digunakan dalam penelitian ini adalah semen portland tipe 1 Semen Holcim kapasitas kemasan $40 \mathrm{~kg}$.

d. Air yang memenuhi syarat dan layak diminum sebagai campuran beton, diambil dari tempat pelaksanaan pembuatan beton

e. Abu ampas tebu berasal dari limbah pabrik gula Madukismo, Yogyakarta.

f. Superplastisizer yang digunakan adalah viscocrete-1003, produk dari PT. Sika Nusa Pratama.

2.3 Peralatan Penelitian

Alat yang digunakan pada penelitian ini dari mulai pemeriksaan bahan sampai dengan benda uji, dengan uraian berikut.

a. Neraca, digunakan untuk menimbang berat bahan penyusun beton.

b. Saringan/ayakan, digunakan untuk mengukur ukuran agregat yang lolos saringan.

c. Kerucut abrams dan baja penumbuk digunakan untuk mengukur nilai slump dari beton segar.

d. Cetakan baja berbentuk silinder dengan tinggi $300 \mathrm{~mm}$ dan diameter $150 \mathrm{~mm}$.

e. Mesin uji tekan beton berkapasitas maksimum $2000 \mathrm{KN}$, yang dilengkapai dengan CPU.

f. Mesin Los Angeles, digunakan untuk menguji tingkat keausan agregat kasar.

g. Concrete mixer/molen, digunakan untuk mengaduk dan mencampur bahan-bahan penyusun beton.

h. Alat pengujian Pengujian Beton Segar flowabilty yang digunakan yaitu Slump Cone Test, V Funnel Test , L-Box Test

VOLUME 11 NO. 2, OKTOBER 2015 | 41 


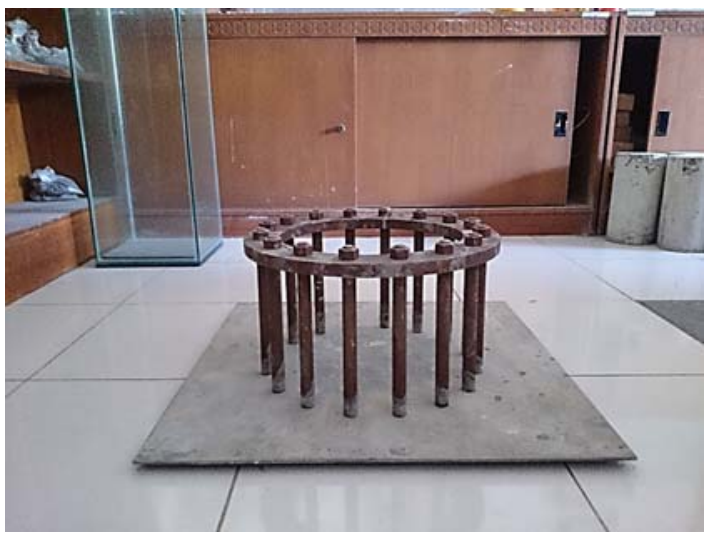

(a)

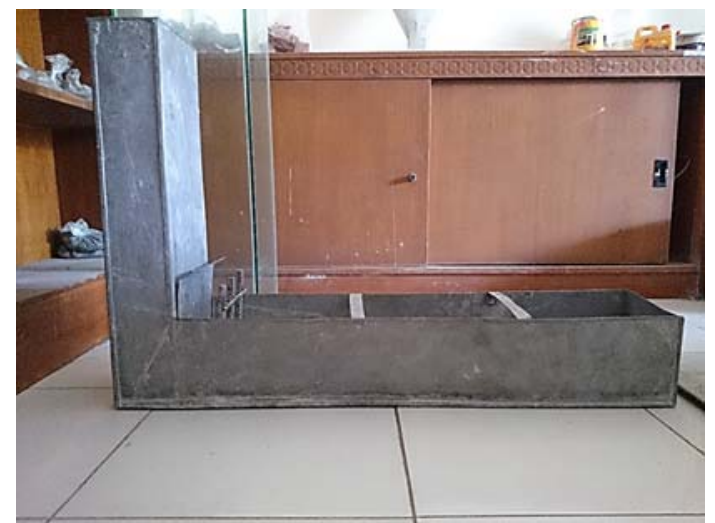

(b)

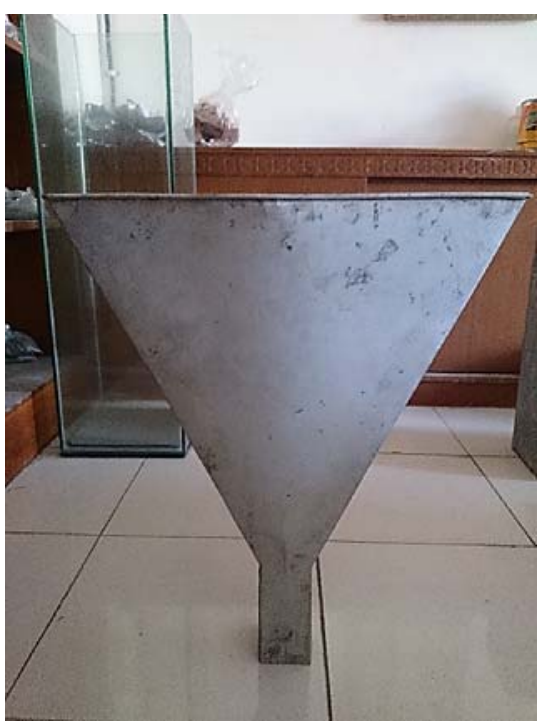

(c)

Gambar 1 (a) Alat pengujian J-Ring; (b) Alat pengujian L-Box; (c) Alat pengujian V-Tunnel

2.4 Prosedur Pengujian

Perlu di lakukan pengujian Sifat Segar Self Compacting Concrete untuk mendapatkan campuran beton dengan flowabilty dan workability yang diinginkan. Adapun langkah-langkah rancang campur beton dan pengujian dari awal sampai akhir adalah sebagai berikut ini.

a. Kerikil ukuran $20 \mathrm{~mm}$ dan pasir pada kondisi saturated surface dry (SSD). Conical mould dengan ukuran diameter atas $3,8 \mathrm{~cm}$, diameter bawah $8,9 \mathrm{~cm}$, tinggi $7,6 \mathrm{~cm}$, lengkap dengan alat penumbuk sebagai alat untuk mengukur keadaan SSD pasir.

b. Siapkan cetakan silinder berdiameter $15 \mathrm{~cm}$ dan tinggi $30 \mathrm{~cm}$.

c. Kerikil ukuran $20 \mathrm{~mm}$ dan pasir ditimbang dan dimasukkan ke tempat pengadukan.

d. Semen tipe 1 (Ordinary Portland Cement) dan AAT dari P.G Madukismo ditimbang kemudian dimasukkan ke tempat pengadukan.

e. Sika Viscocrete 10 ditimbang kemudian dicampurkan ke dalam air yang telah disiapkan dalam gelas ukur. Sebelum campuran air dengan Sika Viscocrete 10 dimasukkan ke tempat pengadukan, campuran agregat kasar, agregat halus, AAT, semen diaduk menggunakan cangkul sampai tercampur rata. Setelah pencampurannya sudah merata air yang telah dicampurkan dengan Sika Viscocrete 10 dimasukkan ke tempat pengadukan secara bertahap dan diaduk menggunakan cangkul sampai adukan beton tercampur merata.

f. Memeriksa flowability dan passingability yaitu dengan pengujian (slump flow, J-Ring flow table) dari adukan beton tersebut.

\section{2 | JURNAL REKAYASA SIPIL}


Cara pengujian flowability dengan slump flow test.

a. Kerucut Abrams diletakkan di atas plat baja pada permukaan yang datar.

b. Kerucut Abrams diletakkan pada posisi terbalik (diameter $10 \mathrm{~cm}$ dibagian bawah dan diameter $20 \mathrm{~cm}$ diatas) diatas plat baja dan diletakkan pada posisi tengah papan aliran.

c. Kerucut Abrams di isi sampai penuh, karena self compacting concrete tanpa dilakukan proses pemadatan.

d. Alat uji kerucut slump di angkat secara perlahan dan tegak lurus keatas dengan papan aliran, sehingga campuran SCC akan turun mengalir membentuk lingkaran.

e. Waktu yang di perlukan adukan beton segar untuk mencapai diameter maksimum $500 \mathrm{~mm}$ di catat dan mengukur diameter sebaran maksimum beton segar.

Cara pengujian passingability (T50 dtik) dengan J-Ring.

a. Alat uji J-Ring dan kerucut Abrams di bahasahi terlebih dahulu dan di letakaan diatas plat baja yang datar.

b. Kerucut Abrams diletakkan pada posisi terbalik (diameter $10 \mathrm{~cm}$ dibagian bawah dan diameter $20 \mathrm{~cm}$ di atas) diatas papan aliran dan diletakkan pada posisi tengah papan aliran dengan J-Ring.

c. Kerucut abrams di isi sampai penuh, karena self compacting concrete maka tidak dilakukan proses pemadatan.

d. Alat uji kerucut slump di angkat secara perlahan dan tegak lurus keatas dengan papan aliran.

e. Ukur dengan cara menghitung beda tinggi antara campuran di dalam lingkaran dengan di luar lingkaran, kemudian catat berapa lama waktu beton untuk mengalir ke diameter $500 \mathrm{~mm}\left(\mathrm{~T}_{50}\right)$.

Cara pengujian flowability dengan $V$-funnel test.

a. Alat uji $V$-funnel test di bersihkan, baik pada rongga maupun penutup di dasarnya.

b. Beton segar di masukkan ke dalam rongga $V$-funnel test dengan bagian penutup di dasarnya dalam keadaan tertutup.

c. Meratakan beton segar pada bagian permukaan alat uji $V$-funnel test.

d. Menempatkan kontainer di bawah alat uji $V$-funnel test.

e. Membuka penutup di dasarnya setelah $(10 \pm 2)$ sejak pengisian alat uji $V$-funnel test.

f. Mencatat waktu pengaliran (tv) sejak penutup alat uji $V$-funnel test dibuka hingga semua beton segar mengalir ke kontainer di bawahnya.

Cara pengujian passingability dengan L-box test.

a. Alat uji L-box test diletakkan pada area yang rata.

b. Beton segar di masukkan ke dalam rongga prisma tegak dengan bagian slide dalam keadaan tertutup.

c. Melepaskan bukaan slide apabila rongga prisma tegak telah terisi penuh.

d. Mencatat waktu pengaliran beton segar sepanjang $20 \mathrm{~cm}$ dan $40 \mathrm{~cm}$ dari bukaan slide.

e. Mencatat nilai h1, yaitu ketinggian beton segar di dalam rongga prisma tegak. Serta nilai h2, yaitu ketinggian beton segar pada ujung luar alat uji $L$-box test.

Tabel 1 Kriteria Persyaratan Self Compacting Concrete (EFNARC, 2002)

\begin{tabular}{cllcc}
\hline & \multicolumn{1}{c}{ Method } & Unit & \multicolumn{2}{c}{ Typical range of values } \\
\cline { 4 - 5 } No. & & & Minimum & Maximum \\
\hline 1. & Slump flow test & Mm & 650 & 800 \\
2. & T50cm slump flow & $\mathrm{Sec}$ & 2 & 5 \\
3. & V-funnel test & $\mathrm{Sec}$ & 6 & 12 \\
4. & V-funnel at T5 minutes & $\mathrm{Sec}$ & 6 & 15 \\
5. & L-Box test & $\mathrm{H} 2 / \mathrm{H} 1$ & 8 & 1.0 \\
\hline
\end{tabular}

VOLUME 11 NO. 2, OKTOBER 2015 | 43 
2.5 Pembuatan Benda Uji

Pembuatan benda uji di laboratorium menggunakan silinder dengan diameter $15 \mathrm{~cm}$ dan tinggi 30 $\mathrm{cm}$, dengan jumlah total benda uji berdasarkan variasi campuran betonnya adalah 18 buah. Bahanbahan yang sudah disiapkan dan ditakar dimasukkan ke dalam mesin pengaduk (molen), mulai dari kerikil dan pasir. Setelah kerikil dan pasir tercampur ditambahkan semen dan abu ampas tebu, kemudian setelah semuanya tercampur merata air dimasukkan sedikit demi sedikit sampai dengan habis sesuai takaran yang ditetapkan. Proses pengadukan dilakukan selama \pm 10 menit hingga diperoleh campuran yang homogen.

\subsection{Perawatan Benda Uji}

Perawatan beton bertujuan untuk menjamin hidrasi semen dengan baik dan dapat menghasilkan kuat tekan beton yang maksimal. Adapun cara perawatannya adalah sebagai berikut.

a. Pada umur beton \pm 24 jam maka cetakan beton dibuka, lalu beton ditimbang untuk mengetahui berat beton.

b. Kemudian beton direndam dalam bak rendaman.

c. Beton diangkat dari bak rendaman dan didiamkan dalam suhu ruangan selama 7 hari dan beton siap untuk diuji tekan setelah umur beton mencapai 28 hari.

d. Sebelum pengujian, dilakukan pengukuran untuk mengetahui diameter dan tinggi silinder.

\section{HASIL DAN PEMBAHASAN}

Hasil pengujian pada penelitian ini dibagi menjadi 2 bagian, yaitu beton pada kondisi segar dan beton keras.

3.1 Hasil pengujian fresh properties berdasarkan variasi

Berdasarkan spesifikasi dari (EFNARC, 2002), campuran beton segar dapat dikatakan sebagai beton SCC apabila memenuhi kriteria filling ability, passing ability, dan segregation resisitance. Cara mendapatkan ketiga kriteria tersebut dilakukan pengujian workabilitas sesuai dengan Tabel 2.

Tabel 2 Hasil pengujian fresh properties berdasarkan variasi penambahan AAT dan Vicocrete 1003 (EFNARC, 2002)

\begin{tabular}{llcccccc}
\hline \multirow{2}{*}{ No } & \multirow{2}{*}{$\begin{array}{c}\text { Jenis } \\
\text { Pengujian }\end{array}$} & Satuan & Spesifikasi & \multicolumn{4}{c}{ Pengujian SCC } \\
\cline { 4 - 7 } & & EFNARC,2002 & & Normal & Mix 1 & Mix 2 & Mix 3 \\
\hline 1 & Slump flow & mm & $650-800(\mathbf{1 0})$ & & & & \\
& & & & 68,2 & 67,7 & 69,7 & 70,9 \\
2 & $\mathrm{~T}_{50} \mathrm{~cm}$ & Detik & $2-5 \mathrm{sec}$ & 2,67 & 2,38 & 2,64 & 2,59 \\
3 & V-Funnel & Detik & $6-12$ & 7,3 & 7,15 & 7,83 & 9,05 \\
4 & L-Box & $\mathrm{H}_{2} / \mathrm{H}_{1}$ & $\mathbf{2} 0,8$ & & & & \\
& & & & 0,95 & 1,4 & 1,65 & 1,87 \\
\hline
\end{tabular}

Keterangan

Normal : Tanpa penambahan AAT dan superplasticizer

Mix 1 : AAT 5\% + Viscocrete 1003 1,2\%

Mix 2 : AAT $10 \%+$ Viscocrete $10031,4 \%$

Mix 3 : AAT 15\% + Viscocrete $10031,6 \%$

Berdasarkan hasil pengujian-pengujian tersebut terlihat bahwa nilai-nilai setiap parameter yang diperoleh untuk jenis ke tiga campuran SCC yang menggunakan abu ampas tebu sebanyak $5 \%$ $15 \%$ berbeda secara signifikan. Hal ini menunjukkan bahwa workabilitas ke tiga jenis campuran tersebut sangat berbeda. Hasil pengujian $j$-ring terdapat beberapa campuran beton yang memiliki sifat passingability yang baik karena sebaran diameter dan waktu alir dari ketiga variasi abu ampas tebu yang dihasilkan baik dan memenuhi syarat sebagai beton SCC, oleh karena itu dapat dikatakan beton tersebut merupakan self compacting concrete (SCC). Dibandingkan dengan variasi kadar $10 \%-15 \%$, beton SCC dengan kadar 5\% memiliki tingkat keenceran yang lebih tinggi. Hal ini dapat dilihat dari pengujian $T 50 \mathrm{~cm}$ dan slump flow. Pada pengujian $\mathrm{T} 50 \mathrm{~cm}$ dan slump flow, 
campuran beton SCC dengan abu ampas tebu 5\% membutuhkan waktu yang lebih pendek untuk mengalir dan mencapai diameter $50 \mathrm{~cm}$ dibandingkan dengan campuran beton SCC dengan penggantian kadar abu ampas tebu $10-15 \%$. Demikian juga pada pengujian, $V$-funnel, tampak bahwa campuran beton SCC dengan abu ampas tebu $5 \%$ lebih cepat keluar dari alat $V$-funnel. Kondisi ini menunjukkan bahwa beton SCC dengan abu ampas tebu memiliki segregation resistance yang lebih baik. Demikian juga dari pengujian $L$-box, diketahui campuran beton SCC dengan abu ampas tebu $5 \%-15 \%$ memenuhi syarat, Artinya, campuran beton SCC tersebut memiliki passing ability yang lebih baik. Hal lain yang menunjukkan indikator suatu beton dikatakan memiliki sifat SCC adalah bila perbandingan $\mathrm{h} 1 / \mathrm{h} 2$ adalah $\geq 0,8$.

a. J-Ring test

$\mathbf{T}_{\mathbf{5 0}}$

(se

c)

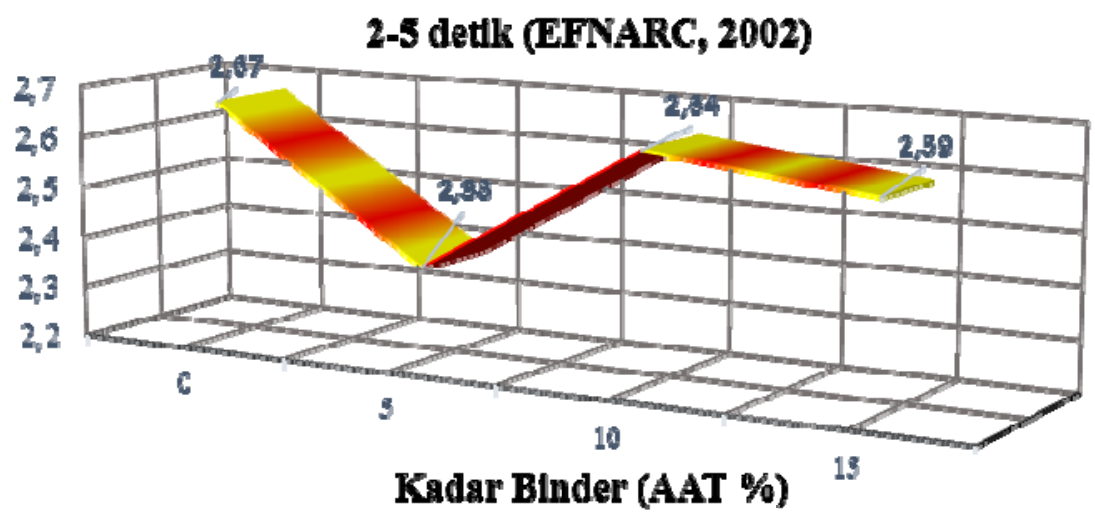

Gambar 2 Hubungan antara komposis binder dan nilai T50 dengan dosis viscocrete yang berbeda

Gambar 2 di atas memperlihatkan nilai T50 (detik) terhadap persentase abu ampas tebu. Secara umum semakin besar persentase abu ampas tebu dalam campuran SCC maka semakin lama beton segar mencapai diameter $50 \mathrm{~cm}$. Nilai T50 berkisar antara 2,38-2,64 detik untuk variasi kadar abu ampas tebu dari $0-15 \%$ dalam campuran beton. Meningkatnya waktu aliran beton segar SCC untuk mencapai diameter $50 \mathrm{~cm}$ (T50) menunjukkan bahwa viskositas beton segar SCC meningkat dengan persentase abu ampas tebu yang tinggi. Jumlah air bebas pada campuran beton segar SCC berkurang karena penyerapan abu ampas tebu yang permukaan spesifik butirannya lebih besar dari pada semen. Oleh karena itu, campuran SCC dengan persentase abu ampas tebu yang lebih besar mengalami hambatan aliran yang lebih tinggi dalam pengujian penyebaran T50. Hambatan aliran tersebut sangat baik untuk menghindari memisahnya pasta beton dengan material lainnya. Pada pengujian dengan komposisi abu ampas tebu $5 \%$, nilai diameter maksimum yang dicapai $\mathrm{T}_{50}$ max sebesar 2,38 .

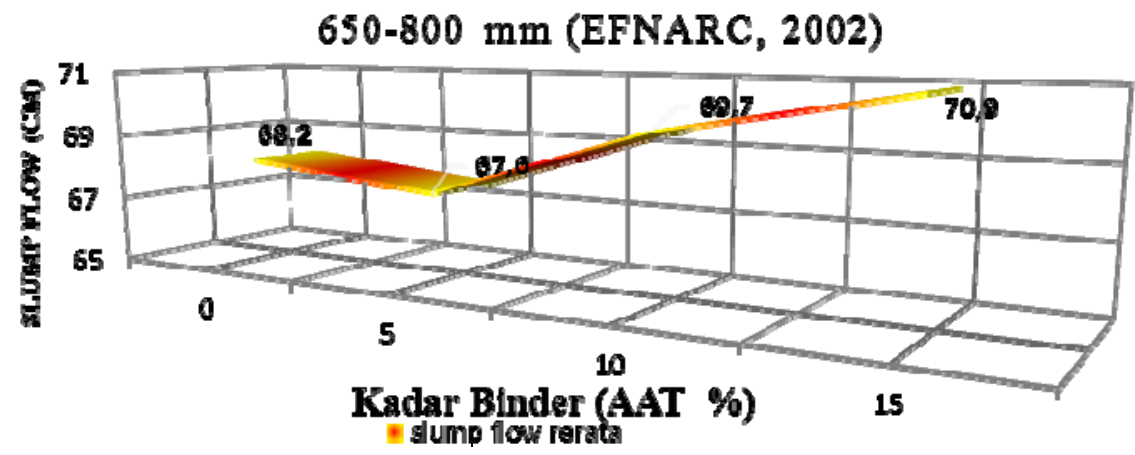

Gambar 3 Hubungan antara komposisi binder dan nilai slump flow $(\mathrm{cm})$ dengan dosis viscocrete yang berbeda 
b. V-Funnel Test

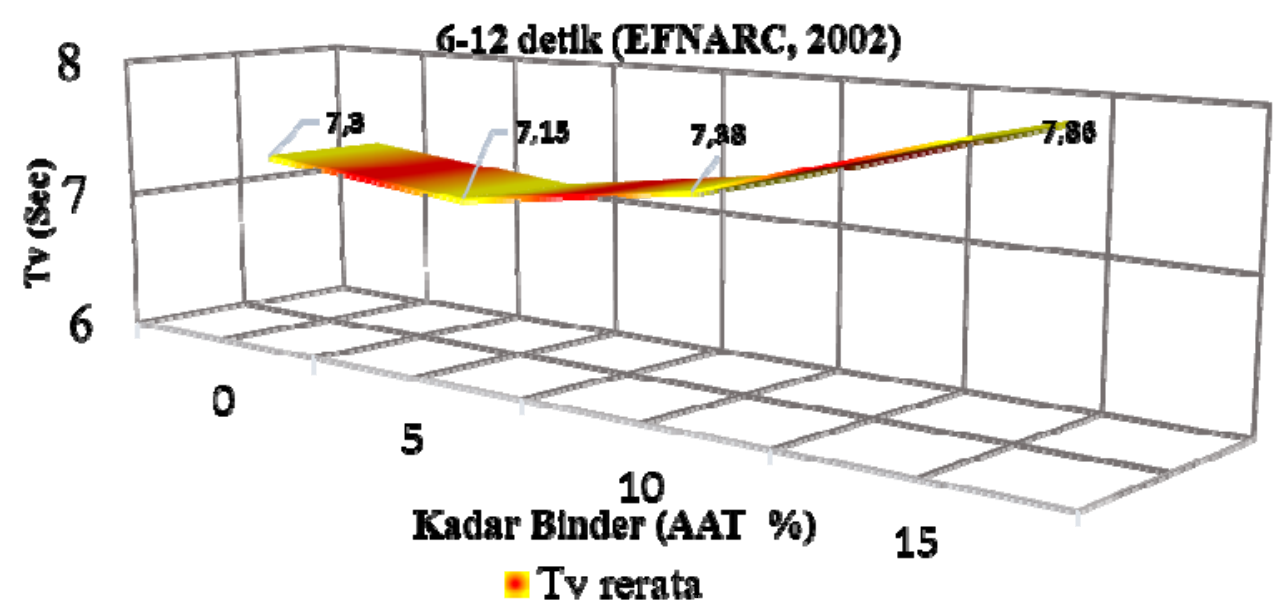

Gambar 4 Hubungan antara komposisi binder dan Tv (sec) dengan dosis viscocrete yang berbeda

Gambar 3 memperlihatkan bahwa aliran slump (slump flow) meningkat saat persentase abu ampas tebu ditambah. Secara umum semakin besar persentase abu ampas tebu dalam campuran SCC maka semakin lama beton segar mencapai diameter $50 \mathrm{~cm}$. Diameter penyebaran beton segar SCC optimum yaitu pada komposisi abu ampas tebu 15\% dengan kadar viscocrete sebesart 1,6\% masih memenuhi standar SCC menurut EFNARC 2002. Berdasarkan hasil pengujian V-Funnel didapat nilai yang bervariasi dari $6,9-7,38$ detik untuk persentase abu ampas tebu $0-15 \%$, sedangkan menurut EFNARC (2002) nilai V-Funnel berkisar antara 6-12 detik. Nilai pengujian ini relatif besar karena water/binder (W/B) SCC yang rendah. Hasil pengujian menunjukkan bahwa waktu yang dibutuhkan beton segar SCC melewati corong pada pengujian $V$-Funnel yang paling optimum adalah 7,15 detik pada kadar abu ampas tebu $5 \%$. Sama seperti slump flow, semakin tinggi kadar abu ampas tebu yang diberikan, maka semakin lama waktu yang dibutuhkan beton segar SCC untuk mengalir. Gambar 4 memperlihatkan kenaikan waktu V-Funnel terhadap peningkatan abu ampas tebu pada beton segar SCC. Besarnya waktu yang dibutuhkan beton segar SCC untuk mengalir juga disebabkan oleh pengaruh kadar ampas tebu yang menyerap air. Ukuran partikel ampas tebu yang kecil dan memiliki ruang pori mengakibatkan adanya daya serapan air bebas pada campuran SCC, sehingga viskositas beton meningkat. Viskositas campuran SCC yang tinggi sangat dibutuhkan untuk menghindari terjadinya segregasi dan bleeding, namun masih dalam keadaan workability yang tinggi. Namun Sebaliknya viskositas yang semakin tinggi juga dapat menyebabkan berkurangnya waktu campuran beton untuk mengalir.

c. L-Box Test

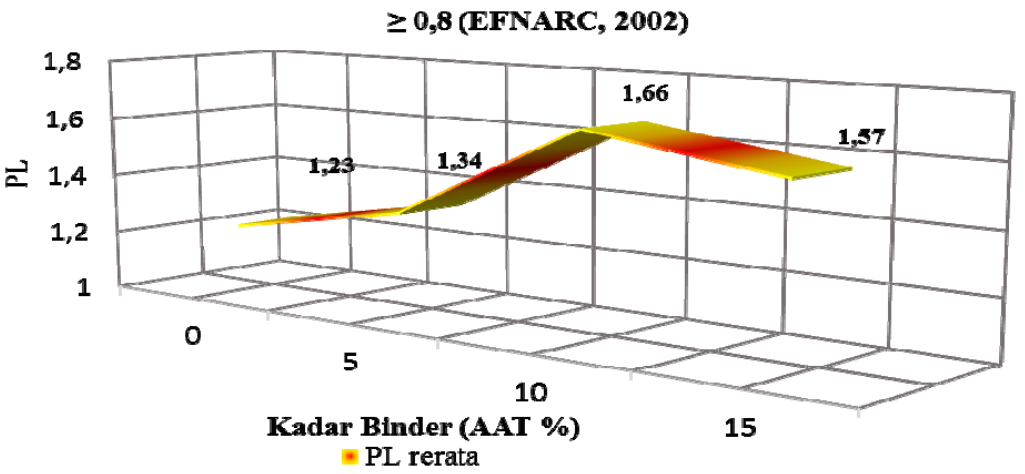

Gambar 5 Hubungan antara komposisi binder dan Tv (sec) dengan dosis viscocrete yang berbeda 
Berdasarkan hasil pengujian $L$-Box didapat nilai yang bervariasi dari 1,23-1,57 detik untuk persentase abu ampas tebu 0 - 15\%, sedangkan menurut EFNARC (2002) nilai $L$-Box sebesar $\geq$ 0,8 . Berdasarkan Gambar 10, dapat dilihat bahwa passing ratio meningkat dengan peningkatan persentase abu ampas tebu dalam SCC. Campuran SCC menggunakan abu ampas tebu paling optimum untuk persentase $10 \%$ yaitu sebesar 1,66 . Hal ini dikarenakan meningkatnya viskositas, karena ampas tebu menyerap air bebas dan menjadikan beton lebih homogen. Semakin meningkat kadar ampas tebu maka campuran SCC menjadi lebih homogen sehingga tidak terjadi pemisahan agregat kasar ketika melewati besi tulangan yang berada di pangkal $L$-Box. Passingability beton SCC semakin meningkat dengan penambahan abu ampas tebu dalam campuran.

Sedangkan kaitannya dengan penambahan viscocrete-1003 dari ke tiga pengujian yaitu $J$-ring, $V$ funnel, dan L-box dengan variasi kadar abu ampas tebu yang berbeda cukup berpengaruh pada flowability dari beton. Hal ini dikarenakan reaksi pada superplasticizer yang menyebabkan sifat cair pada campuran sehingga mampu meningkatkan flowability. Semakin banyak kadar viscocrete1003 yang digunakan akan semakin bepengaruh pada flowability dan workability, hanya saja karena pengaruh kadar ampas tebu yang menyerap air, jadi pengaruh dari penggunaan viscocrete1003 tidak terlihat secara signifikan.

\subsection{Hasil Pengujian Kuat Tekan Beton}

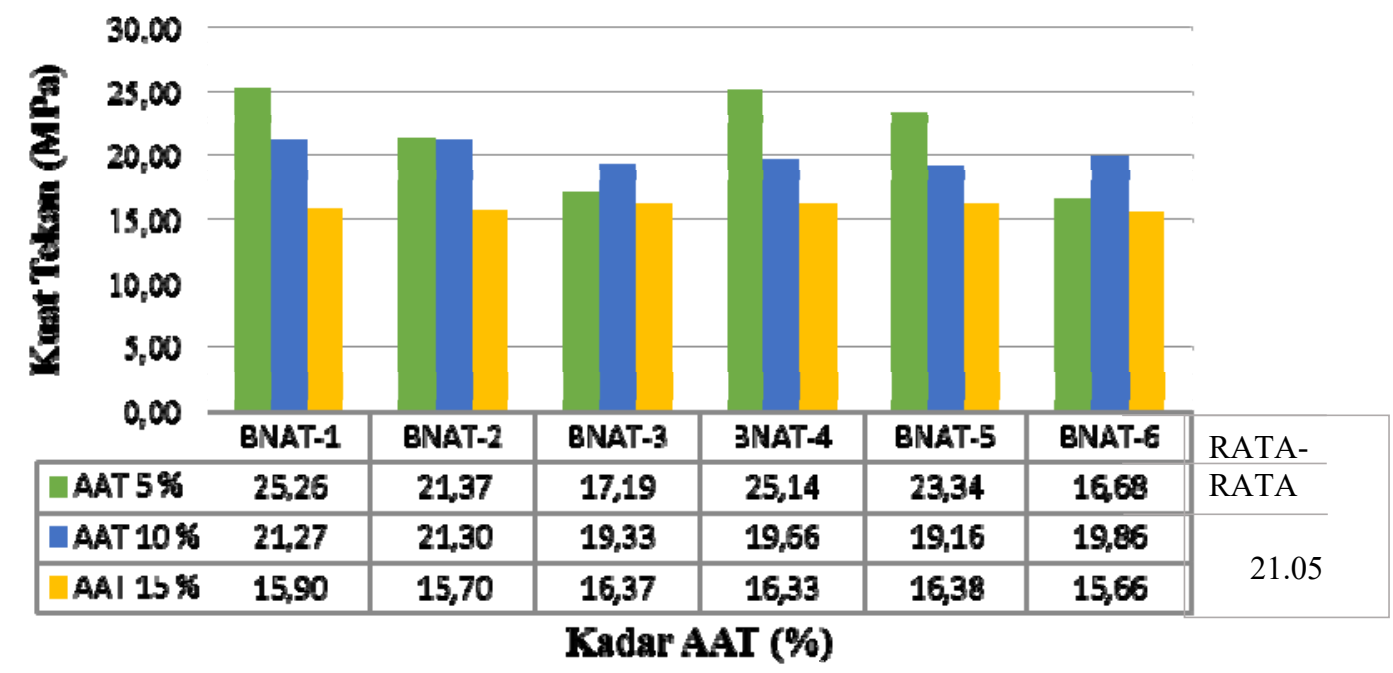

Gambar 6 Perbandingan kuat tekan beton dengan variasi penambahan Abu ampas tebu

Berdasarkan Gambar 6 menunjukkan hasil pengujian kuat tekan self compacting concrete dengan berbagai variasi persentase substitusi semen dengan serbuk abu ampas tebu, semakin kecil bahan penganti sebagian semen maka semakin tinggi kuat tekan beton tersebut. Hal ini berarti dengan penambahan abu ampas tebu dapat mempengaruhi kuat tekan beton mutu tinggi. Dapat dilihat perbandingan kuat tekan beton variasi abu ampas tebu 5\%; 10\%; dan 15\%. Pada saat umur 28 hari terlihat penggunaan penambahan abu ampas tebu 5\% dengan kode benda uji BNAT-1 memiliki nilai kuat tekan beton tertinggi yaitu sebesar 25,26 MPa serta terdapat nilai uji kuat tekan terendah pada variasi abu ampas tebu 15\% dengan kode benda uji BNAT-6 yaitu sebesar 15,66 MPa. Hal ini terjadi karena abu ampas tebu tergolong sebagai pozolan aktif, sehingga jika semen portland, air, pozolan dan agregat bercampur di dalam beton, maka terjadi reaksi hidrasi dari senyawa-senyawa semen dan hidrasi dari komponen mineral pozolan dengan kalsium hidroksida yang dihasilkan oleh hidrasi semen portland. Dengan bertambahnya filler dalam kandungan semen ke dalam campuran, maka akan mengurangi kuat tekan beton yang seharusnya dapat dicapai atau dengan kata lain

VOLUME 11 NO. 2, OKTOBER 2015 | 47 
pengurangan sebagian semen yang di gantikan dengan abu ampas tebu justru senakin semakin menurun kuat tekannya.

Berdasarkan Gambar 7 dapat dilihat bahwa nilai kuat tekan beton, menurun seiring dengan penambahan kadar abu ampas tebu. Penambahan abu ampas tebu sangat berpengaruh pada kuat tekan beton, semakin banyak abu ampas tebu yang digunakan maka kuat tekan beton akan semakin rendah. Penambahan abu sekam padi $5 \%$ nilai kuat tekan beton memiliki rentang atau jarak pada masing-masing benda uji. Pada penambahan abu ampas tebu 10\% nilai kuat tekan antar benda uji memiliki selisih yang tidak jauh antar benda uji, sedangkan pada penambahan abu ampas tebu $15 \%$ kuat tekan beton pada masing-masing benda uji tidak terlalu jauh.

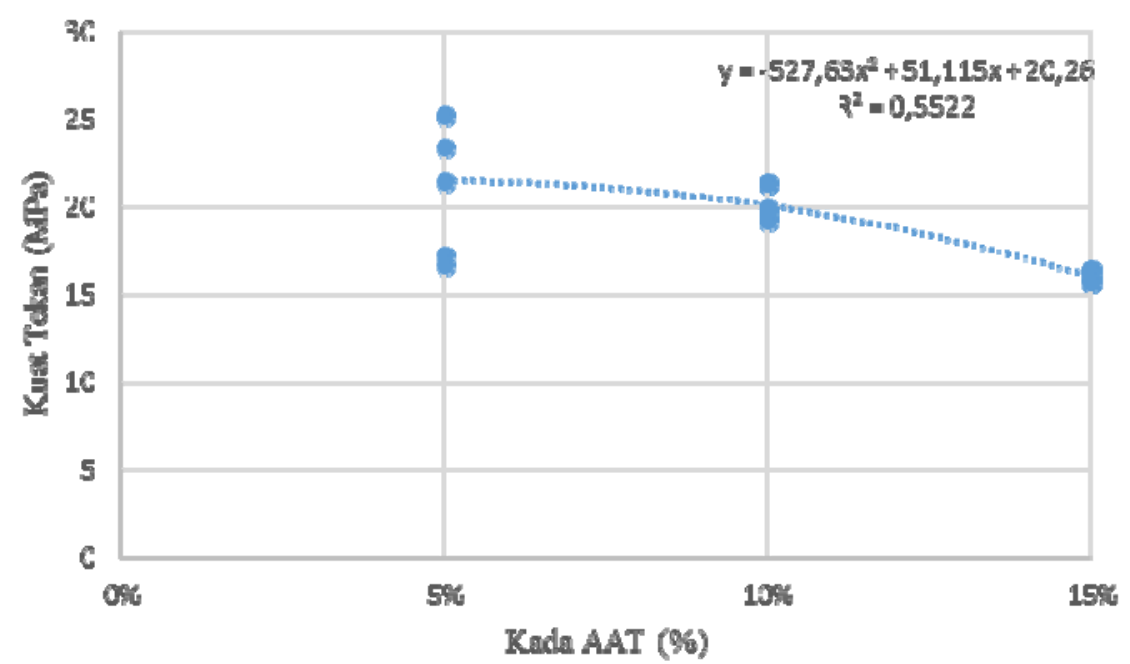

Gambar 7 Penambahan kadar AAT terhadap kuat tekan

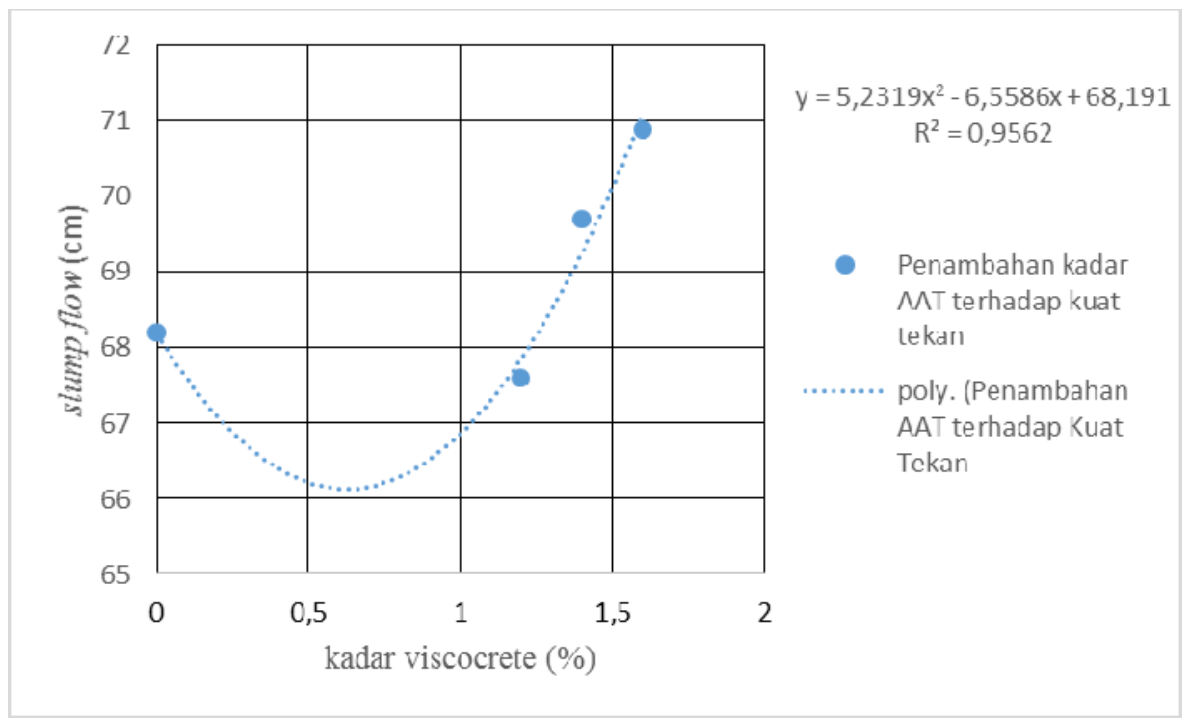

Gambar 8 Hubungan nilai slump low dan Superplasticizer 
Gambar 8 tampak bahwa dengan bertambahnya variasi Superplasticizer maka semakin tinggi nilai slump Hal ini disebapkan dengan semakin banyak variasi Superplasticizer maka tingkat kelecakan atau workability cukup baik meskipun pada pengujian kuat tekan cukup kecil. Nilai slump flow yang didapat pada setiap variasi superplasticizer $1,2 \%, 1,4 \%$, dan $1,6 \%$ yaitu sebesar $67,6 \mathrm{~cm}$, $69,7 \mathrm{~cm}$, dan $70,9 \mathrm{~cm}$. Nilai slump optimum yang diperoleh yaitu $70,9 \mathrm{~cm}$. Pengujian kuat tekan SCC menunjukkan bahwa kuat tekan awal yang besar. Hal tersebut disebabkan oleh proses hidrasi pasta semen yang terus meningkat yang memperkuat ikatan antar material serta adanya penambahan superplastizizer yang menggurangi kadar rongga udara di dalam beton.

\section{KESIMPULAN DAN SARAN}

Berdasarkan hasil analisa penelitian Self Compacting Concrete dengan pemanfaatan Abu Ampas Tebu dan Superplascizer jenis Viscocrete-1003 diambil beberapa kesimpulan sebagai berikut.

a. Kuat tekan maksimal pada umur 28 hari didapat pada komposisi campuran variasi abu ampas tebu dengan persentase $5 \%$ dari berat semen yaitu sebesar 21,50 Mpa, sedangkan pemakaian abu ampas tebu sebesar $10 \%$, dan $15 \%$ menyebabkan penurunan kuat tekan. Besarnya kuat tekan untuk kadar abu ampas tebu $5 \%$ dan $10 \%$ berturut-turut adalah 20,50 MPa dan 16,10 MPa. Penambahan abu ampas tebu pada kadar 5\% ke 10\% mengalami penurunan kuat tekan sebesar $6,96 \%$ dan penurunan juga terjadi pada kadar $10 \%$ ke $15 \%$ sebesar $25,1 \%$. Hal ini menunjukkan bahwa penurunan kuat tekan beton di sebabkan karena adanya pengurangan dari berat semen.

b. Penambahan abu ampas tebu terhadap pengujian beton pada kondisi segar (fresh properties) dari variasi $3 \%, 5 \%$ dan $15 \%$ telah memenuhi standar yang telah ditetapkan oleh EFNARC. Pada pengujian J-Ring (T50 cm dan slump flow) campuran beton SCC dengan abu ampas tebu $5 \%$ memiliki sifat passingability yang baik yaitu 2,38 detik untuk mengalir dan mencapai diameter $50 \mathrm{~cm}$ dengan waktu yang lebih pendek dibandingkan dengan campuran beton SCC dengan penggantian kadar abu ampas tebu $10-15 \%$. Pada pengujian $V$-Funnel menunjukkan bahwa campuran beton SCC paling optimum adalah7,15 detik dengan abu ampas tebu $5 \%$ lebih cepat keluar dari alat $V$-funnel. Kondisi ini menunjukkan bahwa beton SCC dengan abu ampas tebu memiliki filling ability yang lebih baik. Sedangkan pada pengujian passing ratio dengan alat $L$-Box meningkat dengan peningkatan persentase abu ampas tebu dalam SCC. Campuran SCC menggunakan abu ampas tebu paling optimum untuk persentase $10 \%$ yaitu sebesar 1,66 .

c. Penambahan viscocrete-1003 dari ke tiga pengujian yaitu J-ring, V-funnel, dan L-box dengan variasi kadar viscocrete-1003 yang berbeda ternyata dapat meningatkan flowability dari beton. Hal ini dikarenakan reaksi pada superplasticizer yang menyebabkan fluiditas pada campuran sehingga mampu meningkatkan flowability. Semakin banyak kadar viscocrete-1003 yang digunakan akan semakin bepengaruh pada flowability dan workability, hanya saja karena pengaruh kadar ampas tebu yang menyerap air.

\section{DAFTAR PUSTAKA}

ASTM. 1982. Standard Specification for Chemical Admixture for Concrete Type F. American Society for Testing Materials, ASTM C 494-82 Philadelphia.

EFNARC.2002. Specification and Guidelines for Self-Compacting Concrete. Surrey GU9 7EN, UK. Okamura, H \& Ouchi, M. 2003. Self- Compacting Concrete. Journal of Advanced Concrete Technology.1: 1 dan 5-15. 